\title{
GLUCOSYLTRANSFERASE PRODUCTION BY KLEBSIELLA SP. K18 AND CONVERSION OF SUCROSE TO PALATINOSE USING IMMOBILIZED CELLS
}

\author{
Daniela C. Orsi ${ }^{1}$; Haroldo Y. Kawaguti'; Hélia H. Sato ${ }^{1 *}$ \\ ${ }^{1}$ Laboratório de Bioquímica de Alimentos, Departamento de Ciência de Alimentos, Faculdade de Engenharia de Alimentos, \\ Universidade Estadual de Campinas, Campinas, SP, Brasil.
}

Submitted: February 15, 2008; Returned to authors for corrections: June 29, 2008; Approved: February 25, 2009.

\begin{abstract}
The strain Klebsiella sp. K18 produces the enzyme glucosyltransferase and catalyses the conversion of sucrose to palatinose, an alternative sugar that presents low cariogenicity. Response Surface Methodology was successfully employed to determine the optimal concentration of culture medium components. Maximum glucosyltransferase production $\left(21.78 \mathrm{U} \mathrm{mL}^{-1}\right)$ was achieved using the optimized medium composed by sugar cane molasses $\left(80 \mathrm{~g} \mathrm{~L}^{-1}\right)$, bacteriological peptone $\left(7 \mathrm{~g} \mathrm{~L}^{-1}\right)$ and yeast extract $\left(20 \mathrm{~g} \mathrm{~L}^{-1}\right)$, after 8 hours of fermentation at $28^{\circ} \mathrm{C}$. The conversion of sucrose to palatinose was studied utilizing immobilized cells in calcium alginate. The effects of the alginate concentration (2-4\%), cell mass concentration (20-40\%) and substrate concentration (25-45\%) were evaluated and the yield of palatinose was approximately $62.5 \%$.
\end{abstract}

Key-words: cell immobilization, glucosyltransferase, Klebsiella sp, palatinose, response surface methodology

\section{INTRODUCTION}

Sucrose is the main sweetener used in food production, however, the excessive and imbalanced consumption of highsucrose foods is a contributory factor to cause obesity and dental caries. In recent decades, the production of new sweeteners as alternative to sucrose has aroused great interest. Palatinose or isomaltulose (6-O- $\alpha$-D-glucopyranosyl-D-fructofuranose) is a reducing sugar and a structural isomer of sucrose, naturally present in honey in small quantities (10). Palatinose is a lowcariogenic sugar (8), selectively promotes growth of beneficial bifido-bacteria among human intestinal microflora (1) and it has sweetener taste and bulk similar to sucrose (12). The safety of applying isomaltulose on diet has been carefully studied, resulting in its approval use as human food (7). Also, palatinose has been used as raw material to produce Isomalt ${ }^{\circledR}$, a sugaralcohol that presents reduced caloric content and noncariogenic features (16). Palatinose is obtained by enzymatic transglucosylation of sucrose using the microorganisms Protaminobacter rubrum (2), Erwinia sp (4,7), Serratia plymuthica (15) and Klebsiella sp $(3,11)$. These bacterias are known to produce the intracellular enzyme $\alpha$-glucosyltransferase (EC 5.4.99.11) transforming sucrose in palatinose. In a previous study it was isolated, from over-ripe fruits, the strain Klebsiella sp. K18 that produces glucosyltransferase and catalyses the conversion of sucrose to palatinose (11). In this work we used response surface methodology to study the combined effect of the components of the media and to optimize their concentration aiming to obtain maximum production of glucosyltransferase. This study, also, aimed to develop a palatinose biocatalyst consisting of Klebsiella sp. K18 cells immobilized in calcium alginate particles.

\section{MATERIALS AND METHODS}

\section{Microorganism}

The strain Klebsiella sp. K18, a glucosyltransferase producing bacterium, was isolated in the Laboratory of Food Biochemistry (State University of Campinas) and used throughout this work. The microorganism was maintained on

*Corresponding Author. Mailing address: Laboratório de Bioquímica de Alimentos, Departamento de Ciência de Alimentos, Faculdade de Engenharia de Alimentos, Universidade Estadual de Campinas (UNICAMP), Rua Monteiro Lobato 80, CEP 13083-862, C.P.6121, Campinas-SP, Brasil. Tel.: +55 19 3521-2165; Fax: +55 19 3521-2153. E-mail: heliah@fea.unicamp.br 
agar slants composed of $6 \%(\mathrm{w} / \mathrm{v})$ sucrose, $4 \%(\mathrm{w} / \mathrm{v})$ peptone, $0.4 \%(\mathrm{w} / \mathrm{v})$ beef extract and $2 \%(\mathrm{w} / \mathrm{v})$ agar.

\section{Culture medium optimization using Response Surface Methodology}

The study for culture medium optimization was carried out using Response Surface Methodology in order to identify optimum parameter levels for glucosyltransferase production. The two level rotatory central composite design $\left(2^{3}-\mathrm{RCCD}\right)$ was used with a combination of the concentration levels of the independent variables (Table 1). The variables studied were sugar cane molasses $\left(10-150 \mathrm{~g} \mathrm{~L}^{-1}\right)$, bacteriological peptone $(0-$ $\left.14 \mathrm{~g} \mathrm{~L}^{-1}\right)$ and yeast extract Prodex ${ }^{\circledast}\left(0-40 \mathrm{~g} \mathrm{~L}^{-1}\right)$. The levels studied with the decoded values are shown in Table 2. All data were treated with the aid of STATISTICA ${ }^{\circledR} 5.5$ from Statsoft Inc. (2325 East 13th Street, Tulsa, OK, 74104, USA). The strain was grown in $250 \mathrm{~mL}$ Erlenmeyer flasks containing $50 \mathrm{~mL}$ of a seed culture medium according to $2^{3}-\mathrm{RCCD}$, for $24 \mathrm{~h}$ at $30^{\circ} \mathrm{C}$ in an orbital shaker (New Brunswick Scientific, Edison, N.J., U.S.A). An aliquot of $5 \mathrm{~mL}$ of the seed culture was transferred to flasks containing $45 \mathrm{~mL}$ of the former medium and incubated at $30^{\circ} \mathrm{C}$ for $12 \mathrm{~h}$, shaken at $200 \mathrm{rpm}$. The culture broth was centrifuged and the cell mass was suspended in $20 \mathrm{~mL}$ citrate-phosphate buffer $0.05 \mathrm{M}, \mathrm{pH}$ 6.0. For the extraction of intracellular enzyme,

Table 1. Experimental design $\left(2^{3}-\mathrm{RCCD}\right)$ and results for glucosyltransferase production by Klebsiella sp. K18.

\begin{tabular}{|c|c|c|c|c|}
\hline \multirow[t]{2}{*}{ Assay } & \multicolumn{3}{|c|}{ Coded variable levels } & \multirow{2}{*}{$\begin{array}{l}\text { Enzyme } \\
\text { activity } \\
\left(\mathrm{UmL}^{-1}\right)\end{array}$} \\
\hline & Molasses $^{\mathrm{a}}$ & Peptone $^{b}$ & $\begin{array}{l}\text { Yeast } \\
\text { extract }^{\mathrm{c}}\end{array}$ & \\
\hline 1 & -1 & -1 & -1 & 4.68 \\
\hline 2 & +1 & -1 & -1 & 7.22 \\
\hline 3 & -1 & +1 & -1 & 5.98 \\
\hline 4 & +1 & +1 & -1 & 8.20 \\
\hline 5 & -1 & -1 & +1 & 7.27 \\
\hline 6 & +1 & -1 & +1 & 6.59 \\
\hline 7 & -1 & +1 & +1 & 7.01 \\
\hline 8 & +1 & +1 & +1 & 7.99 \\
\hline 9 & -1.68 & 0 & 0 & 3.01 \\
\hline 10 & +1.68 & 0 & 0 & 8.05 \\
\hline 11 & 0 & -1.68 & 0 & 6.34 \\
\hline 12 & 0 & +1.68 & 0 & 7.87 \\
\hline 13 & 0 & 0 & -1.68 & 8.28 \\
\hline 14 & 0 & 0 & +1.68 & 6.28 \\
\hline 15 & 0 & 0 & 0 & 9.79 \\
\hline 16 & 0 & 0 & 0 & 10.15 \\
\hline 17 & 0 & 0 & 0 & 9.88 \\
\hline
\end{tabular}

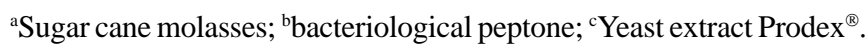

Table 2. Design experimental levels of media constituents $\left(\mathrm{g} \mathrm{L}^{-1}\right)$.

\begin{tabular}{lccccc}
\hline \multirow{2}{*}{\multicolumn{1}{c}{ Variables }} & \multicolumn{5}{c}{ Levels of media constituents } \\
& \multicolumn{5}{c}{$\left(\mathrm{g} \mathrm{L}^{-1}\right)$} \\
\cline { 2 - 6 } & -1.68 & -1 & 0 & +1 & 1.68 \\
\hline Sugar cane molasses & 10.0 & 38.3 & 80.0 & 121.7 & 150.0 \\
Bacteriological peptone & 0 & 2.8 & 7.0 & 11.2 & 14.0 \\
Yeast extract Prodex $^{\circledast}$ & 0 & 8.1 & 20.0 & 31.9 & 40.0 \\
\hline
\end{tabular}

the cell mass was disrupted by ultrasonic vibration Labline UltraTip (Labline Instruments, Inc., Illinois, USA). After cell wall disruption, the samples were centrifuged and the enzyme activity of the supernatant was determined.

\section{Batch enzyme kinetic studies and production of cell biomass}

Cell biomass production was performed in a 6.6-L bioreactor New Brunswick Bioflo IIc (New Brunswick Scientific, Edison, NJ, USA) with a 3.0-L working volume. The growth of microorganism, alteration of the $\mathrm{pH}$ culture medium and the production of glucosyltransferase were carried out at $26^{\circ} \mathrm{C}, 28^{\circ} \mathrm{C}$, $30^{\circ} \mathrm{C}$ and $35^{\circ} \mathrm{C}$. A loop full of culture was inoculated in $250 \mathrm{~mL}$ Erlenmeyer flasks containing $50 \mathrm{~mL}$ of culture medium optimized and incubated in an orbital shaker $200 \mathrm{rpm}$ at $30^{\circ} \mathrm{C}$ for $24 \mathrm{~h}$. An aliquot of $300 \mathrm{~mL}$ of seed culture was inoculated in the bioreactor containing $2700 \mathrm{~mL}$ of the optimized medium. The airflow rate was $1 \mathrm{vvm}$ and the agitation speed was set at $200 \mathrm{rpm}$. Samples were collected at time-defined intervals and submitted to analysis.

\section{Analytical methods}

The glucosyltransferase activity was performed by increasing the reducing power from a solution containing sucrose, according to Park et al. (11). A mixture of $0,45 \mathrm{~mL}$ of a $4 \%(\mathrm{w} / \mathrm{v})$ sucrose solution in $0.05 \mathrm{M}$ citrate-phosphate buffer $\mathrm{pH} 6.0$ and $0,05 \mathrm{~mL}$ of enzyme solution was incubated for $20 \mathrm{~min}$ at $35^{\circ} \mathrm{C}$. Reducing sugars were measured by Somogy method (12) using glucose as standard. One activity unit (U) of glucosyltransferase is defined as the amount of enzyme that liberates one $\mu \mathrm{mol}$ of reducing sugars minute ${ }^{-1} \mathrm{~mL}^{-1}$ from sucrose under standard assay conditions. A Beckman DU 70 spectrophotometer (Beckman-Coulter, Inc., Fullerton, CA, USA) was used to monitoring cell growth by measurement of the optical density at $660 \mathrm{~nm}\left(\mathrm{OD}_{660}\right)$ and the $\mathrm{pH}$ of the culture medium was measured with a potentiometer.

\section{Immobilization method and conversion of sucrose to palatinose}

The sodium alginate solution was mixed with appropriate amount of the cell suspension in the volume proportion of 1:2. Immobilized beads were prepared by drop wise extrusion of the 
cell-alginate suspension in $2 \%(\mathrm{w} / \mathrm{v}) \mathrm{CaCl}_{2}$ solution using a MasterFlexs L/S multichannel peristaltic pump (ColeParmer Instrument Co., Vernon Hills, Il, USA) to form $3 \mathrm{~mm}$ diameter beads, which were maintained immersed in the same solution for $12 \mathrm{~h}$ at $5^{\circ} \mathrm{C}$. The beads were then washed with sterile distilled water and transferred to packed-bed reactors $(150 \mathrm{~mm}$ x $30 \mathrm{~mm})$ maintained at $30^{\circ} \mathrm{C}$. Sucrose solution was then passed through the reactors in an ascending flow of approximately $2 \mathrm{~mL} \mathrm{min.}{ }^{-1}$. Values of sodium alginate concentrations (2-3\%), cell mass concentrations (20-40\%) and substrate concentrations (25-45\%) were used for studying their effect on the conversion of sucrose to palatinose.

\section{Sugar analysis}

The sugar determination was conducted by HPLC-PAD. The HPLC analysis was performed using a DIONEX-DX 600 chromatograph with an IP25 isocratic pump and an electrochemical detector. A Carboc Pac ${ }^{\mathrm{TM}} \mathrm{PA} 1$ column $(4 \mathrm{~mm} \times 250$ $\mathrm{mm}$ ) and a $250 \mathrm{mM}$ sodium hydroxide solution as the mobile phase were used for the sugar separation. The flow rate was 1 $\mathrm{mL} \min ^{-1}$ at $20^{\circ} \mathrm{C}$ and the carbohydrates were analyzed comparing their retention times with those of fructose, glucose, sucrose and palatinose standards (Sigma Ultra ${ }^{\circledR}$-Sigma Chemical Co., St. Louis, MO, USA).

\section{RESULTS AND DISCUSSIONS}

\section{Culture medium optimization using Response Surface Methodology}

Response Surface Methodology was employed to evaluate the levels of the variables that significantly affected the dependent variable, named as glucosyltransferase activity. The effect estimates for the $2^{3}$-FCCD for each variable, sugar cane molasses, bacteriological peptone and yeast extract Prodex $^{\circledR}$ were reported in Table 3. The analysis of the effects demonstrates that the linear main effects of sugar cane molasses $(p<0.0026)$ and bacteriological peptone $(p<0.0130)$ were highly significant and had positive influence in the enzyme activity. This suggest that the concentrations of these components had a direct relationship with the glucosyltransferase production. Statistical evaluation of the model was made by Fisher's test, obtained from analysis of variance, whose results are shown in Table 4. Based on the $F$ test, the model is predictive, since its calculated $F$ value is higher than the critical $F$ value ( $F_{\text {model }}$ exceeded the tabulated value $F_{0.95,6,10}$ by 4.4 times). The pure error was very low (0.03), indicating good reproducibility of the model obtained. The $R$-square value (coefficient of determination) provides a measurement of how much the variability observed in the response values could be explained by the experimental factors and their interactions. A good model can explain most of the variations in the response and the closer $R$-square value is to 1.0 , the better are the response predictions. In this study the
Table 3. Main effects of media constituents for glucosyltransferase production by Klebsiella sp. K18 from the 23-RCCD.

\begin{tabular}{lrcrl}
\hline \multicolumn{1}{c}{ Factor } & Effect & Std. error & t-value & p-value \\
\hline (1) Molasses (L) & 1.98 & 0.10 & 19.54 & $0.0026^{*}$ \\
Molasses (Q) & -2.93 & 0.11 & -26.21 & $0.0014^{*}$ \\
(2) Peptone (L) & 0.88 & 0.10 & 8.65 & $0.0130^{*}$ \\
Peptone (Q) & -1.81 & 0.11 & -16.2 & $0.0037^{*}$ \\
(3) Yeast extract (L) & -0.08 & 0.10 & -0.83 & 0.4901 \\
Yeast extract (Q) & -1.69 & 0.11 & -15.12 & $0.0043^{*}$ \\
(1) x (2) & 0.33 & 0.13 & 2.52 & $0.0472^{*}$ \\
(1) X (3) & -1.11 & 0.13 & -8.41 & $0.0138^{*}$ \\
(2) X (3) & -0.28 & 0.13 & -2.15 & 0.1643 \\
\hline
\end{tabular}

(L) Linear factor; (Q) Quadratic factor; * Significant factors $(\mathrm{p} \leq 0.05)$.

Table 4. ANOVA for the experimental design $\left(2^{3}-\mathrm{RCCD}\right)$ used to evaluate the significance of the model.

\begin{tabular}{lcccc}
\hline $\begin{array}{l}\text { Source of } \\
\text { variation }\end{array}$ & $\begin{array}{c}\text { Sun of } \\
\text { quares }\end{array}$ & $\begin{array}{c}\text { Degrees } \\
\text { of freedom }\end{array}$ & $\begin{array}{c}\text { Means } \\
\text { quare }\end{array}$ & $\begin{array}{c}F_{\text {ratio }} \\
\text { (model } \\
\text { significance) }\end{array}$ \\
\hline Regression & 46.76 & 06 & 7.79 & $11.28^{\mathrm{a}}$ \\
Residual & 6.93 & 10 & 0.69 & \\
Lack of fit & 6.86 & 08 & 0.85 & \\
Pure error & 0.07 & 2 & 0.03 & \\
Total & 53.70 & 16 & & \\
\hline
\end{tabular}

Coefficient of determination $R^{2}=0.878 ; F_{0.95,6,10}=2.55$;

${ }^{\mathrm{a}} F_{\text {ratio }}($ regression/residual).

adequacy of the model was obtained with a good determination coefficient $\left(\mathrm{R}^{2}=0.878\right)$.

On the basis of ANOVA, a second order model (Equation 1) was established, describing the glucosyltransferase activity $(Y)$ as a function of sugar cane molasses $\left(X_{1}\right)$; bacteriological peptone $\left(X_{2}\right)$; and, yeast extract Prode ${ }^{\circledR}\left(X_{3}\right)$. The coded model was used to generate response surfaces and contour curves (Fig.1) for the analysis of the variable effects on glucosyltransferase activity.

$$
\begin{aligned}
& Y=9.91+0.99 . X_{1}+0.44 . X_{2}-1.46 . X_{1}^{2} \\
& -0.90 . X_{2}^{2}-0.84 . X_{3}^{2}-0.56 . X_{1} . X_{3}
\end{aligned}
$$

The response surfaces and contour curves represented the predicted model, indicating the levels of the variables for an optimal process. The model predicted the maximum activity in culture medium composed by sugar cane molasses $80 \mathrm{~g} \mathrm{~L}^{-1}$, bacteriological peptone $7 \mathrm{~g} \mathrm{~L}^{-1}$ and yeast extract Prodex ${ }^{\circledR} 20 \mathrm{~g} \mathrm{~L}^{-1}$. 
(a)

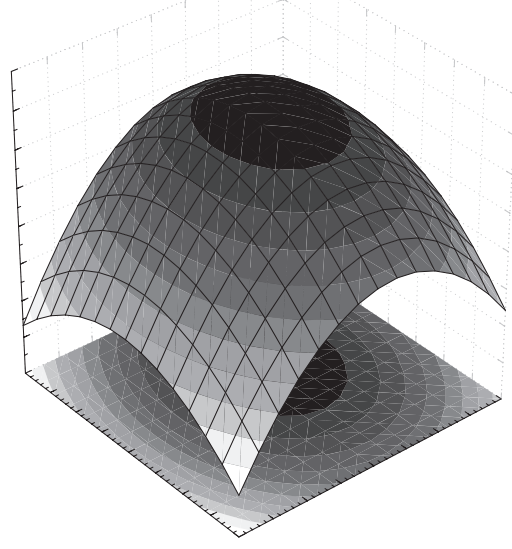

(b)

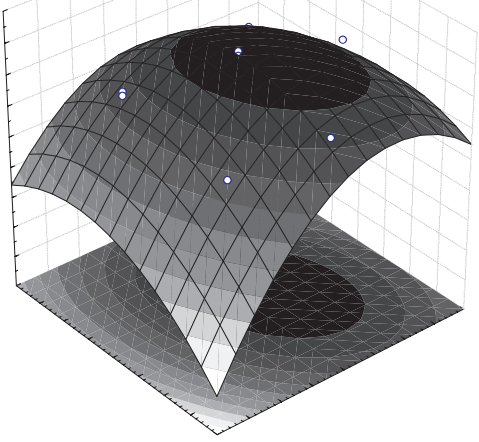

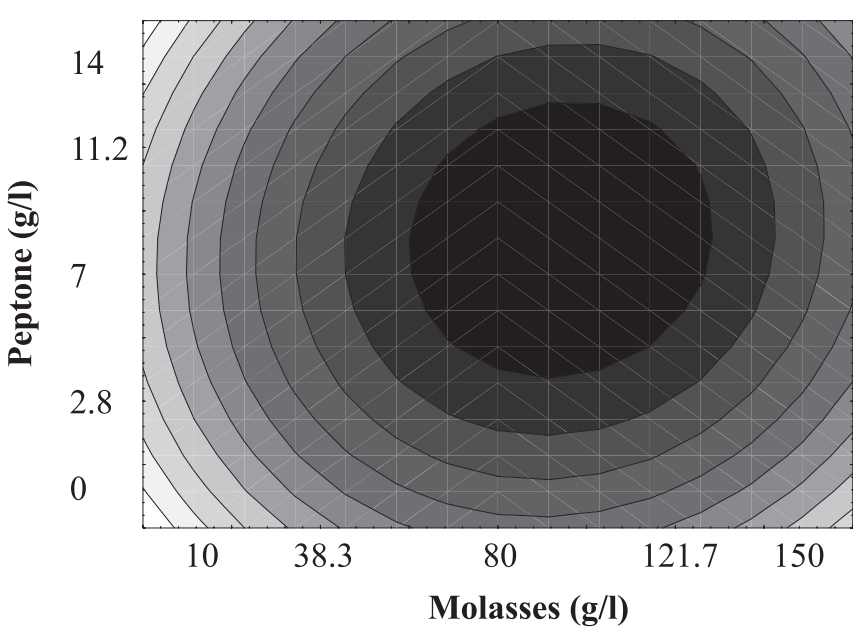

40

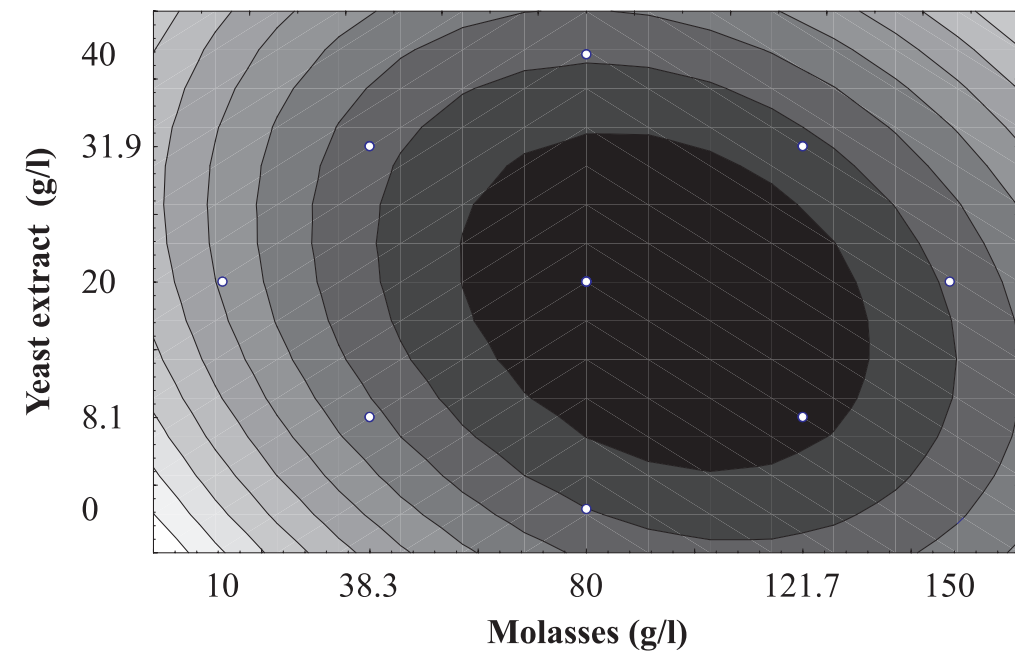

Figure 1. Response surfaces and contour curves for glucosyltransferase activity from Klebsiella sp. K18: (a) as a function of sugar cane molasses and bacteriological peptone and (b) as a function of sugar cane molasses and yeast extract Prodex ${ }^{\circledR}$, according to the experimental design $\left(2^{3}-\mathrm{RCCD}\right)$.

After $12 \mathrm{~h}$. of fermentation at $30^{\circ} \mathrm{C}$ was obtained $9.94 \mathrm{U} \mathrm{mL}^{-1}$ (average of the central points).

Kawaguti et al. (5) obtained $6.65 \mathrm{U} \mathrm{mL}^{-1}$ of glucosyltranferase activity from Erwinia sp cells, after $15 \mathrm{~h}$ of fermentation at $30^{\circ} \mathrm{C}$, using the optimized culture medium composed by sugar cane molasses $100 \mathrm{~g} \mathrm{~L}^{-1}$, corn steep liquor $60 \mathrm{~g} \mathrm{~L}^{-1}$ and yeast extract 8 $\mathrm{g} \mathrm{L}^{-1}$. The medium components sugar cane molasses and corn steep liquor (agroindustrial by-products) were used with the purpose of resulting in a low cost culture media. In this work, the strain Klebsiella sp. K18 showed low activity with the media utilized before (11). So, we studied the possibility of using medium components substitutes like sugar cane molasses and yeast extract Prodex ${ }^{\circledR}$ as well as use Response Surface Methodology for media optimization to increase the glucosyltransferase production. After media optimization, the activity of glucosyltransferase was increased from 2.95 to 9.94 $\mathrm{U} \mathrm{mL}^{-1}$, approximately 3.4 times higher in correlation to the media used before (11), composed by sucrose $4 \%(\mathrm{w} / \mathrm{v})$, bacteriological peptone $1 \%(\mathrm{w} / \mathrm{v})$ and beef extract $0.4 \%(\mathrm{w} / \mathrm{v})$. In addition, components sugar cane molasses and yeast extract Prodex ${ }^{\circledR}$ were useful carbon and nitrogen source for enzyme production and they are cheaper components than sucrose and beef extract, what have contributed to reduce costs in the fermentation process. 
Batch enzyme kinetic studies and production of cell biomass

After optimization of the culture medium components, the influence of temperature on the growth of Klebsiella sp. K18 to produce cell mass and glucosyltransferase in a 6.6-L bioreactor was assayed. Fig. 2 illustrates the glucosyltransferase production and cellular growth at temperatures ranging from $26^{\circ} \mathrm{C}$ to $35^{\circ} \mathrm{C}$. The microorganism fermentations at different temperatures showed similar growth profiles and characteristics. The enzyme activity increased at the beginning of the cultivation ( $2 \mathrm{~h}$ of fermentation time) and reached a maximum level after $8 \mathrm{~h}$, coinciding with the exponential growth phase, which characterized this enzyme as primary metabolic ones. Comparing fermentation at different temperatures, glucosyltransferase production was lower during fermentation at $35^{\circ} \mathrm{C}$ than those observed at $26^{\circ} \mathrm{C}, 28^{\circ} \mathrm{C}$ or $30^{\circ} \mathrm{C}$. Moreover, the $\mathrm{pH}$ of the culture medium was about 5.7-5.3 during fermentations, suggesting little production of acid as a byproduct. Maximum glucosyltransferase activity of $21.75 \mathrm{U} \mathrm{mL}^{-1}$ was obtained after $8 \mathrm{~h}$ of fermentation at $28^{\circ} \mathrm{C}$.
Moraes et al. (9) using the strain Erwinia sp obtained a glucosyltranferase activity of $15.61 \mathrm{U} \mathrm{mL}^{-1}$ after $8 \mathrm{~h}$ of fermentation at $30^{\circ} \mathrm{C}$, whose culture medium was composed by sugar cane molasses $12 \%(\mathrm{w} / \mathrm{v})$, bacteriological peptone $4 \%$ $(\mathrm{w} / \mathrm{v})$ and beef extract $0.4 \%(\mathrm{w} / \mathrm{v})$. The glucosyltransferase production from Erwinia sp was lower during fermentation at $32^{\circ} \mathrm{C}$, due to enzyme thermosensibility. Other works, observed for glucosyltransferase-producing strains, such as Klebsiella planticola (3), Serratia plymuthica (15), Protaminobacter rubrum (2), Erwinia sp (4) that the biomass concentration increased during the first 8 to $24 \mathrm{~h}$ of fermentations at temperatures ranging from $26^{\circ} \mathrm{C}$ to $30^{\circ} \mathrm{C}$.

\section{Conversion of sucrose to palatinose using immobilized cells}

The cell biomass of strain Klebsiella sp. K18 was obtained from bioreactor fermentation at $28^{\circ} \mathrm{C}$, using culture medium optimized, as previously described. Three concentrations ( $2 \%$, $3 \%$ and $4 \% \mathrm{w} / \mathrm{v}$ ) of sodium alginate were tested for cell immobilization. The effect of alginate concentration on

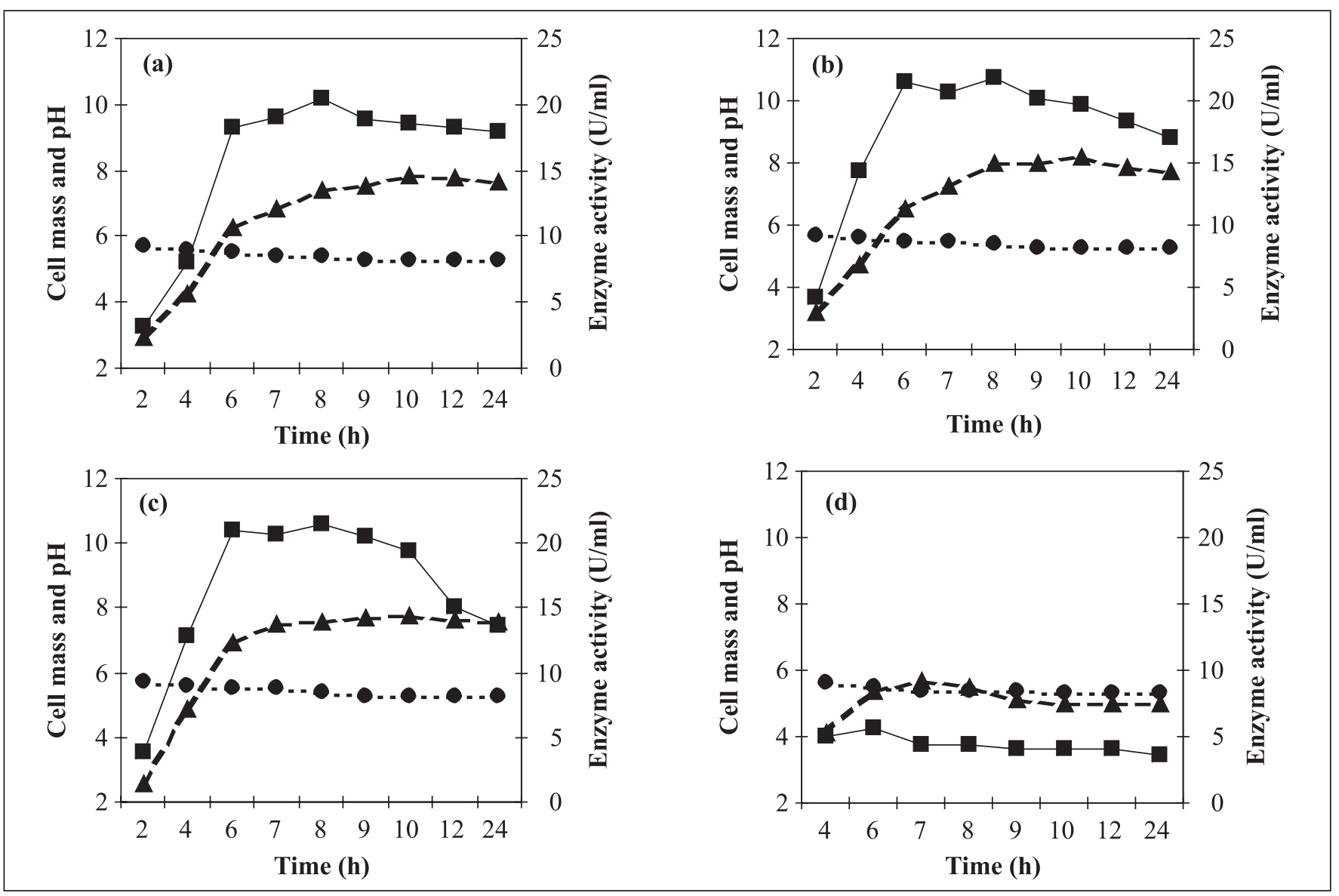

Figure 2. Study of the growth of the strain Klebsiella sp. K18 and production of glucosyltransferase at: (a) $26^{\circ} \mathrm{C}$, (b) $28^{\circ} \mathrm{C}$, (c) $30^{\circ} \mathrm{C}$ and (d) $35^{\circ} \mathrm{C}(\boldsymbol{\square}$ enzyme activity, $\boldsymbol{\Delta}$ cell mass and $\boldsymbol{p H})$. 
palatinose production was showed at Fig. 3. The highest palatinose production $(62.1 \%)$ was obtained with beads prepared from $2 \%$ calcium alginate, after $24 \mathrm{~h}$ of reaction. As the alginate concentration increased ( $3 \%$ and $4 \%$ ), the conversion of sucrose to palatinose was reduced, may be due to the lower diffusion efficiency of beads. The immobilized cells in alginate $4 \%$ showed lower palatinose production and the conversion rate decreased quickly to $31.4 \%$, after $72 \mathrm{~h}$. Also, the immobilized cells in sodium alginate $2 \%$ and $3 \%$ showed slightly decreasing on conversion rates, reaching of $52.6 \%$ and $48.3 \%$ respectively, after $72 \mathrm{~h}$.

The effect of cell loading on palatinose production was investigated in the next experiment, using immobilized cells in $2 \%$ alginate concentration. The conversion of sucrose to palatinose using $20 \%, 30 \%$ and $40 \%(\mathrm{w} / \mathrm{v})$ cellular concentrations were $62.5 \%, 56.8 \%$ and $56.0 \%$, respectively, after $24 \mathrm{~h}$, as showed in Fig. 4. The beads with a cellular concentration of $20 \%$ and $30 \%$, decreased slightly to $52.8 \%$ and $52.5 \%$ respectively, after $72 \mathrm{~h}$. However, the beads with a cellular concentration of $40 \%$ showed a great decrease on palatinose production $(18.0 \%)$, after $72 \mathrm{~h}$. The rapidly decrease on palatinose production at high cell concentration occurred perhaps because the bead strength was affected and cells started coming out from the beads.

In the following experiment, the effect of different concentrations of substrate $(25 \%, 35 \%$ and $45 \% \mathrm{w} / \mathrm{v})$ on palatinose production was studied using cells immobilized in $2 \%$ alginate concentration and $20 \%$ cellular concentration and the results are shown in Fig. 5. Maximum palatinose conversion rate $(62.3 \%)$ was achieved, after 24 h., at $35 \%$ sucrose concentration. Based in the results of this work, it was concluded

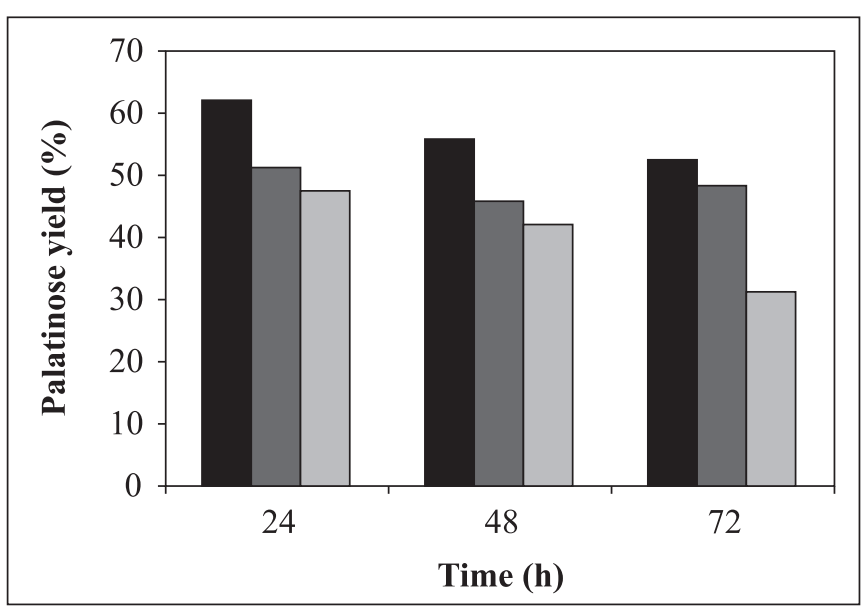

Figure 3. Conversion of sucrose to palatinose using immobilized cells, at varying alginate concentrations ( $\mathbf{a}$ sodium alginate $2 \%$, sodium alginate $3 \%$ and $\square$ sodium alginate $4 \%$ ). that $2 \%$ alginate concentration, $20 \%$ cellular concentration and $35 \%$ sucrose concentration showed optimal result on palatinose production with immobilized cells. Using these conditions it was obtained approximately $62.5 \%$ of palatinose conversion rate after $24 \mathrm{~h}$ and the conversion rate decreased slightly to approximately $52.6 \%$ after $72 \mathrm{~h}$. The biocatalyst consisted of Klebsiella sp. K18 immobilized cells in calcium alginate showed an efficient palatinose-bioconversion.

These results were in accordance with other works. Tsuyuki et al. (14) obtained $65.4 \%$ of palatinose from a $20 \%$ sucrose solution using Klebsiella planticola MX10 cells immobilized

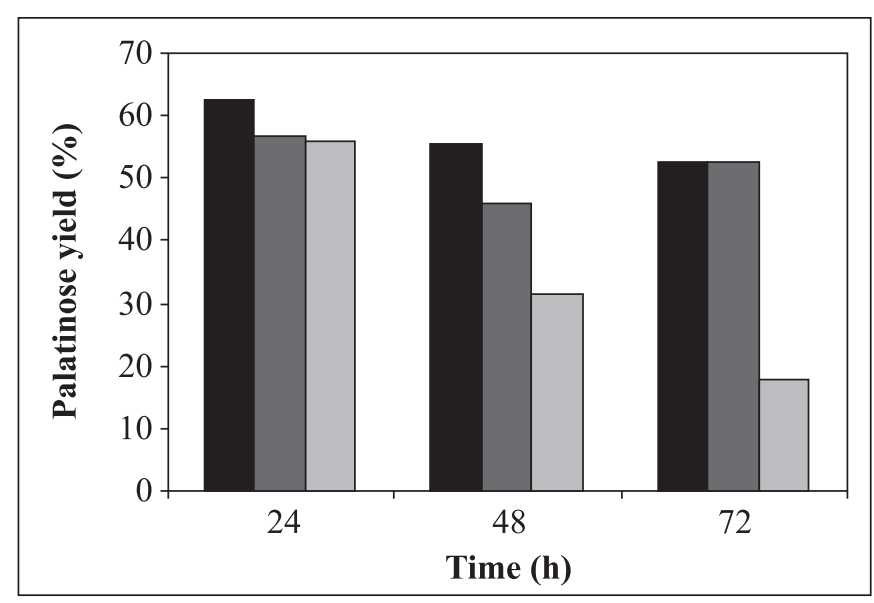

Figure 4. Conversion of sucrose to palatinose using immobilized cells in alginate $2 \%$, at varying cellular concentrations ( $\mathbf{C}$ cell mass $20 \%$, cell mass $30 \%$ and $\square$ cell mass $40 \%$ ).

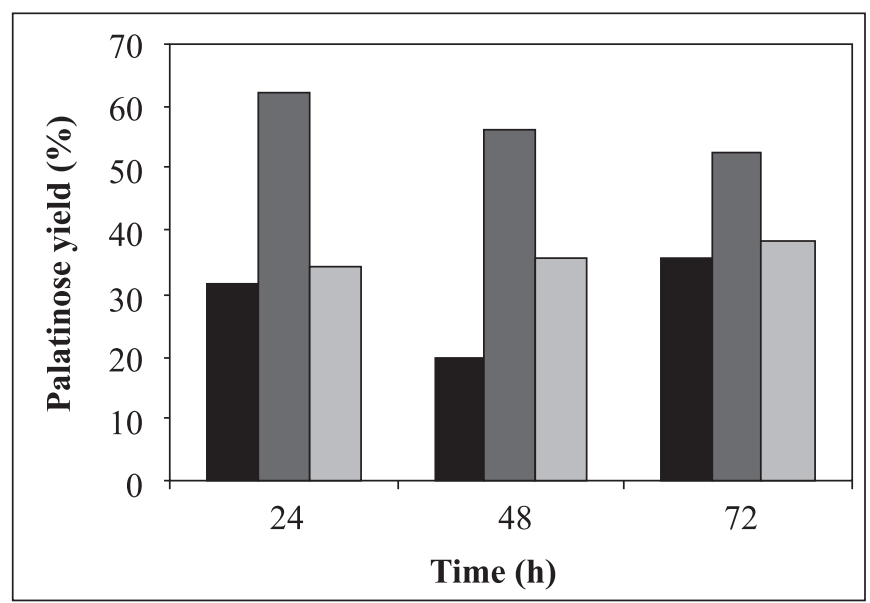

Figure 5. Conversion of sucrose to palatinose using cell mass $20 \%$ immobilized in alginate $2 \%$, at varying substrate concentrations ( $\square$ sucrose solution $25 \%$, $\square$ sucrose solution $35 \%$ and sucrose solution $45 \%$ ). 
in $4 \%$ alginate. Li et al. (6) observed that Klebsiella sp LX 3 cells immobilized in $2 \%$ alginate and packed in $200 \mathrm{~mL}$ column reactors converted $65 \%$ of palatinose from a $30 \%$ sucrose solution passed through the column reactors in a flow speed of $2 \mathrm{~mL} \mathrm{~min}{ }^{-1}$. Moraes et al. (9) studied the effects of sucrose concentration on palatinose production, using Erwinia sp immobilized cells in calcium alginate. Cells (20\% wet cells/v) entrapped in $1 \%$ alginate were packed in column reactors and sucrose solutions of different concentrations $(12.5-60 \%, \mathrm{w} / \mathrm{v})$ were passed through the columns. After $24 \mathrm{~h}$ of reaction, at $35^{\circ} \mathrm{C}$, the yield of palatinose was approximately $50 \%$ from sucrose solutions ranging from $20 \%$ to $30 \%$. The excess of sucrose (40-60\%) affected the activity of the immobilized cells, decreasing the conversion of sucrose to palatinose.

\section{ACKNOWLEDGEMENTS}

The authors thank the financial assistance extended by the Coordenação de Pessoal de Nível Superior (CAPES).

\section{RESUMO}

\section{Produção de glicosiltransferase por Klebsiella sp. K18 e conversão de sacarose em palatinose utilizando células imobilizadas}

A linhagem Klebsiella sp. K18 produz a enzima glicosiltransferase que catalisa a conversão de sacarose em palatinose, um açúcar alternativo que apresenta baixa cariogenicidade. Metodologia de Superfície de Resposta foi empregada com sucesso para determinar a concentração ótima dos componentes do meio de cultivo. A máxima produção de glicosiltransferase $\left(21,78 \mathrm{U} \mathrm{mL}^{-1}\right)$ foi obtida utilizando o meio de cultivo otimizado composto por melaço de cana de açúcar $(80 \mathrm{~g}$ $\left.\mathrm{L}^{-1}\right)$, peptona bacteriológica $\left(7 \mathrm{~g} \mathrm{~L}^{-1}\right)$ e extrato de levedura $(20 \mathrm{~g}$ $\mathrm{L}^{-1}$ ), após 8 horas de fermentação a $28^{\circ} \mathrm{C}$. A conversão de sacarose em palatinose foi estudada utilizando células imobilizadas em alginato de cálcio. Os efeitos da concentração de alginato (2-4\%), concentração de massa celular (20-40\%) e concentração de substrato (25-45\%) foram avaliados e a porcentagem de palatinose foi de aproximadamente $62,5 \%$.

Palavras-chave: imobilização celular, glicosiltransferase, Klebsiella sp, palatinose, metodologia de superfície de resposta

\section{REFERENCES}

1. Cummings, J.H.; MacFarlane, G.T.E.; Englyst, H.N. (2001). Prebiotic digestion and fermentation. American J. Clin., 73, 415-420.

2. Heikkila, H.; Sarkki, M.; Lindroos, M.; Ojala, P.; Ravanko, V.; Tylli, M. (2000). Process of the production of isomaltulose and other products U.S. Pat. 6, 146, 856.

3. Huang, J.H.; Hsu, L.H.; Su, Y.C.; (1998). Conversion of sucrose to isomaltulose by Klebsiella planticola CCRC 19112. J. Ind. Microbiol. Biotechnol. 21, 22-27.

4. Kawaguti, Y.H; Manrich, E.; Sato, H.H. (2006). Production of isomaltulose using Erwinia sp D12 cells: Culture medium optimization and cell immobilization in alginate. Biochem. Eng. J., 29, 270-277.

5. Kawaguti, Y.H; Manrich, E.; Fleuri, F.L.; Sato, H.H. (2005). Production of glucosyltransferase by Erwinia sp using experimental design and response surface methodology. Braz. J. Microbiol. 36, 227-234.

6. Li, X.; Zhao, C.; An, Q.; Zhang, D. (2003). Substrate induction of isomaltulose synthase in a newly isolated Klebsiella sp. LX3, J. Appl. Microbiol. 95, 521-527.

7. Lina, B.A.R.; Jonker, D.; Kozianowski, G. (2002) Isomaltulose (Palatinose): a review of biological and toxicological studies. Food Chem. Toxicol. 40, 1375-1381.

8. Minami, T.; Fujiwara, T.; Ooshima, T.; Nakajima, Y.; Hamada, S. (1990). Interaction of structural isomers of sucrose in the reaction between sucrose and glucosyltransferases from mutans Streptococci, Oral Microbiol. Immunol. 5, 189-94.

9. Moraes, A.L.L.; Steckelberg, C.; Sato, H.H.; Pinheiro, A. (2005). Produção de isomaltulose a partir da transformação enzimática da sacarose, utilizando-se Erwinia sp D12 imobilizada com alginato de cálcio. Ciênc. Tecnol. Aliment. 25, 95-102

10. Moreira, R.F.; Maria, C.A. (2001). Glicídios no mel. Quím. Nova, 24, 516-525.

11. Park, Y.K.; Uekane, R.T.; Sato, H.H. (1996). Biochemical characterization of a microbial glucosyltransferase that converts sucrose to palatinose. Rev. Microbiol. 27, 131-136

12. Somogy, M. (1945). A new reagent for the determination of sugars. J. Biol. Chem. 160, 61-68.

13. Takazoe, I. (1989). Palatinose-an isomeric alternative to sucrose, In: Elsevier Applied Science (ed). Progress in Sweeteners. London, England, p. 143-167

14. Tsuyuki, K.; Sugitani, Y.; Miyata, Y.; Ebashi, T.; Nakajima, Y. (1992). Isolation and characterization of trealulose-producing bacteria from Thailand soil, J. Gen. Appl. Microbiol. 38, 483-490.

15. Veronese, T.; Perlot, P. (1999). Mechanism of sucrose conversion by the sucrose isomerase of Serratia plymuthica ATCC 15928. Enzyme Microb. Technol. 24, 263-269.

16. Ziesenitz, C.S.; Sibert, G. (1987). The metabolism and utilization of polyois and other bulk sweeteners compared with sugar. In: Elsevier Applied Science (ed). Developments in sweeteners. London, England, p. 109-149. 